\title{
Literature and the Press: Afterword
}

\section{Laura Marcus}

The five essays published here, wide-ranging as they are in their cultural and historical references and explorations, all make their contributions to an area of increasing interest in literary and historical studies: the role of the periodical press in cultural and political life and the importance of press and publishing history to an understanding of literary texts and formations. The focusing of the essays around two moments - 'around 1800' and 'around 1900' - points up the ways in which the ends of centuries can be particularly charged and formative periods. In the case of the two periods in question, the essays reveal how crucial the press was in the making and dissemination of social, political and literary ideas and ideals, and in the creation of oppositional spaces or 'counterpublic spheres'.

As literary historians of the eighteenth century and of the Romantic period have shown, journals played a crucial role in the ways in which knowledge was conceptualized and organized, with the fictional world becoming central to the organization of knowledge in the Romantic period. The 'serious' general magazine or Review was a product of the mid-eighteenth century and, as Marilyn Butler has written, the new journals created occupied cultural spaces both outside and largely independent of the established institutions of learning and (by contrast with Germany) aristocratic patronage. Following Jon Klancher's work on journals and readership in the Romantic period, Butler notes that, while 'journals implied a community of discourse that united its scattered members and over time distinguished their idiolects from those of the national community, this social identity was also divisive; 'as journals proliferated, what they registered was the play within the community of different idiolects': 
Journals provided a notional "public sphere" deeply compromised from the start, since the egalitarian relationship of writer and reader and the classless status claimed for the reader were always sharply contradicted by the real world of widely unequal incomes, rank and power. In the very period in which "discourse" took on definition and offered itself as a subject for analysis, it was foregrounding, as Klancher shows, its own instability. Beguiling the reader with the pleasures and rewards of knowledge, the journals' mode of presenting knowledge - fragmentary, arbitrary, selective, contested, could never satisfy the more intoxicating promises of enlightenment. ${ }^{1}$

The war with revolutionary France that began in 1793 spelt an end to the hopes for reform of the Dissenters who were the owners and editors of the major 'literary' journals 'around 1800': the Monthly Review, the Critical Review, the English Review and the Analytical Review. Support for liberal causes became not only marginalized and counter-cultural but also increasingly identified, in negative ways, with literary culture, producing a profound effect on the literary figures of the period.

These dimensions of literature and the press at the end of the eighteenth century are explored in the essays published here by Luisa Calé and Felicity James. While Matthew Beaumont analyses the visual iconography used on the cover of the 1890s feminist paper Shafts, Calé opens up the significance of visual satire in the antiJacobin representations of the radical press, and the production of 'a coherent agency of sedition'. She also explores, through the case study of Joseph Priestley's

Theological Repository, the implications of pseudonymity and anonymity in ways that bear not only on the journals of the period she discusses, but also on those at the turn of the nineteenth and twentieth centuries. 'Pseudonyms', she argues, 'mark the threshold of the periodical sphere', while anonymity 'tells us that the sphere of periodicals has its own rules; it is a free space where arguments should run for 
themselves'. At the same time, the adoption of names provided necessary protection in a politically troubled period. Her researches into authorship and signature, anonymity and pseudonymity, open up 'the perfomativity and theatricality of public utterance', as well as the fraught nature of oppositional writing.

Felicity James' 'Writing in Dissent: Coleridge and the Poetry of the Monthly Magazine' contributes in significant ways to the periodizing theme of the essays published here, as James shows how the Monthly was Janus-faced in its temporalities, looking both backwards to earlier eighteenth-century periodical modes - including ‘earlier models of friendship, exchange and sociability’ - while engaging emphatically with the debates of the 1790s. She also addresses a number of themes and preoccupations that run throughout all the essays and which have striking relevance to both the historical periods under discussion: the relationship between the individual and the periodical voice; the dangers attendant upon dissident writing; the role of literature and the literary in the periodical press; and the concept of the 'public sphere', including the re-reading and revising of its most influential formulations in the work of Jurgen Habermas.

The period from 1890 to the beginning of World War One in Britain also saw intense activity in relation to politics and the press. As Mark Morrison and others have shown, socialists and anarchists, observing the enormous expansion of the commercial press, and adducing from it the increasing activity of the Liberal and Conservative parties, saw the creation of their own presses as the most effective political move. The Independent Labour Party financed sixty-eight papers between 1893 and 1910, while syndicalists and anarchists produced at least twenty-five anarchist papers from 1890-1910, forming the Metropolitan Co-Operative Printing Works to print the major anarchist papers and to avoid prosecution for sedition. The 
suffrage cause found its most powerful voice in its journals, many of which, with their largely, and large, middle-class readerships, were substantially funded by commercial advertising revenues: in this context a highly complex relationship emerged between the new and oppositional periodical press and establishment and commercial culture. ${ }^{2}$ It is these contexts that framed the journals published 'around 1900', discussed in the three essays published here.

Matthew Beaumont, in his essay on the liberal-feminist newspaper Shafts, 'Influential Force: Shafts and the Diffusion of Knowledge at the Fin de Siècle', uses the iconography of the journal's cover - itself a form of advertising - to open up the question of the journal's self-image and its presentation to its readers. He further examines the ways in which germ theory, which had gained increasing scientific currency in the 1890s, was used as a metaphor in the pages of the paper to explore intellectual influences. As he notes, 'germs' has a dual meaning, referring both to 'microbes proliferating among unhealthy bodies' and 'seeds fructifying in healthy soil', and thus holding together the contradictory denotations of generation and of contamination. The word 'dissemination' is defined by the O.E.D. in terms which include 'dispersion, diffusion, promulgation, and a scattering or spreading abroad, as of a seed'. Its figurative meanings include 'to spread abroad, diffuse, promulgate (opinions, statements, knowledge)'. Beaumont uses the metaphor of 'the germ' (directly deployed by the Pre-Raphaelites in the title of their journal) to explore the spreading of ideas, pointing up the complexities of models of dissemination and diffusion in the late nineteenth century at a time when spiritualist ideas, encompassing models of the transmission of knowledge across boundaries, were a significant force. As he notes, the opposition, at the fin de siècle, between rationalism and irrationalism, enlightenment and anti-enlightenment, was an unstable one, with occultism and 
psychical research deployed in the service of cultural transmission and communication.

The question of 'unofficial knowledge' and its diffusions bears interestingly on the upholding of enlightenment values (Beaumont notes the ways in which 'enlightenment' was redefined in 1890s contexts as an 'influential force' encompassing spiritual and physical as well as intellectual processes), the concepts of a 'public sphere' and the valorisation of 'disinterestedness' that governed many of the new journals in the first years of the twentieth century. Ford Madox Ford's English Review (founded in 1909) defined itself as an 'Enlightenment' journal, ‘ a general intelligencer', and was modelled on the Mercure de France, in a context in which France stood for Enlightenment. The editorial policy of Orage's New Age, which he took over in 1907, was also governed by models of eighteenth-century prose and of the public sphere in which the journal would operate, but at the same time revealed the very strong influences of Nietzsche, theosophy and philosophies of 'will' and 'ego’.

Such philosophies - of 'will', ‘striving' and ‘self-making' - were crucial to the cultural fraction of working-class, self-taught writers such as John Davidson and, a little later, Edwin Muir. They were also of central significance to women for whom the models of 'egoism' espoused by thinkers such as Nietzsche, Max Stirner and Otto Weininger (whose 1903 study Sex and Character was translated into English in 1906 and, for all its apparent misogyny, was profoundly important for many feminist thinkers) represented an escape from the ideological prison of feminine 'altruism'. It remains an open question, however, as to how the absolute elevation of 'ego' was to be related to the collective public space created and represented by the new journals. 
We might also pause here to consider the ways in which issues of naming, authorship and pseudonymity, raised in such interesting ways in the two essays printed here on late eighteenth-century journals, recur in late nineteenth-century and early twentieth-century contexts.

The changing names of journals, as a reflection of changed editorships, altered editorial policy or as a way of redefining the nature of a journal's readership, is a significant, and largely overlooked, dimension of press and publishing history, and late nineteenth- and early twentieth-century journals offer some striking examples. The 'free-lifer' Charles Daniel's journal, to which the novelist Dorothy Richardson contributed, began life in 1906 as Crank, becoming Ye Crank in 1907, and subsequently Ye Crank and the Open Road, finally ending up as The Open Road. The New Age was founded in 1894 as The New Age: A Weekly Record of Culture, Social Service and Literary Life, becoming, in 1895, The New Age: A Journal for Thinkers and Workers and in 1907, when A.R. Orage became Editor, The New Age: an Independent Socialist Review of Politics, Literature and Art: the term 'independent' in the last title indicates Orage's concern to differentiate his brand of socialism from that of the Fabians. Most strikingly, perhaps, Dora Marsden’s The Freewoman of 1911 became The New Freewoman of 1913 and, in its final years (1914-1919), The Egoist. Names and naming are significant themes in the three essays on the 1890s published here. The Anglo-Russian, the title of one of the two journals examined in Carol Peaker’s essay ‘We are not Barbarians: Literature and the Russian Émigré Press in England, 1890-1905', provided a model of dialogue and conjunction and, at the same time, and in more complex ways, of double-voicing. It suggests the extent to which the project of the journal was to militate against English concepts of Russia as 'the primitive', while opening up the question of the ways in which the journal was to 
speak to its Russian readers. A different version of the theme of the double voice emerges in Anne Humpherys 'The Journals that Did: Writing about Sex in the 1890s', in the discussion of the aliases adopted by Roland de Villiers/George Astor Singer, owner and editor of the Free Review, which became the University Magazine and Free Review and, in 1899, the University Magazine. Here the name-changes indicate the transgressive nature of the journal while, as Humpherys shows, the overlap of authors and subjects in the journals of the 1890s she discusses gives 'a sense of the shape of the virtual community of a free thought periodical response to the sexual problem'. At the same time, the silence in the periodicals on the question of the Wilde trials (by contrast with the extensive reportage in the daily press) indicates, in Laurel Brake’s words, 'the extent of anxiety attaching to gender as a subject and the constraints on its discourses' ${ }^{3}$

More generally, the question of 'authorship' in the history of journalism comes to the fore, with debates over the respective effects of anonymous and signed journalism and the striking paradox, or perhaps logic, of charismatic editors combined with uncertainties about the authorial voice. The voice, or voices, might be anonymous, ventriloquized or seemingly multiple - the journalistic 'we' - while in fact stemming from a single source, raising complex questions of consensus and diversity. Orage apparently subscribed to the precept that a good editor never writes a line, but in fact he assumed a number of pseudonyms in the presentation of the New Age copy which he authored, and it would seem that he wrote a substantial part of the journal himself.

In a different but related context, the centrality of readers' voices crosses the permeable borders between authorship inside and outside a journal's parameters. The Freewoman, for example, set up discussion circles, an initiative to which Rebecca 
West was central: participants would listen to a lecture, which would be published in the pages of the magazine, and then discuss the topic in print. The journal was increasingly dominated by its correspondence section, so that readers, as in the late eighteenth-century contexts discussed here, became writers and contributors. The nature and identity of a journal’s ‘authorship’ was indeed dispersed and diffused.

The question of 'identities' arises in a further context in the 1890s and the early years of the twentieth-century: a period which saw the formation of the ‘modern’ disciplines, including sexology and psychoanalytic psychology, sociology, and literary studies. Journals played a highly significant role in these formations, with a strongly utopian cast to many of the turn of the century periodicals and magazines, committed to forms of anarchism, socialism, free union, or the planned society. Utopian thinking and writing also brought together the spheres of literature and sociology, with, as in the Romantic journals discussed earlier, imaginative literature playing a central, though at times contested, role in social and political thought. In the context of the Russian emigré journals, as Carol Peaker shows, the role of fiction and imaginative literature generally was to represent a Russian 'culture’ which militated against the received images of its 'barbarism'.

Turgenev was the first Russian writer to be fully appreciated by English writers, though, as Lytton Strachey noted in an article in the Spectator in 1912, his reputation was subsequently diminished by the arrival of 'the giant figure of Tolstoy' on the literary scene. ${ }^{4}$ Interest in Dostoevsky grew steadily from the first years of the twentieth century onwards. The Dostoevsky reception had in fact begun at the end of the nineteenth century in England, on a wave of interest in Russia, though he was not widely read until the translation of The Brothers Karamazov appeared in 1912. He was, in many ways, received and read as a 'modernist' rather than a nineteenth- 
century writer, absorbed into the new cultural renaissance, along with psychoanalysis, Bergsonism, and post-impressionism. Russian culture and literature was also central to the journals and 'little magazines' of the modernist period, including the New Age and T. S. Eliot's Criterion in its first years, which published material by Dostoevsky, Tolstoy and Andreev. The Dostoevsky contribution (the Virginia Woolf-S. S. Koteliansky translation 'Plan of the Novel, “The Life of a Great Sinner”') was, Eliot wrote to Koteliansky, 'the most important thing in no.1' of the Criterion. ${ }^{5}$ The seeds of this reception were undoubtedly sown in the emigré journals of the turn of the century.

Imaginative writing was also an extremely important feature of the feminist journals, Shafts among them, and it is indeed the case that feminism, perhaps more than any other political movement, has used literary texts to make and disseminate its meanings. The role of literature in the periodical press took on new dimensions in the early twentieth century, as journals such as the Freewoman were increasingly governed by literary contributions, becoming almost entirely literary by the point of its remaking as the Egoist. The relationship between its feminism (anti-statist, nonsuffrage, anti-parlimentarian and free-thinking) and the literary and artistic avantgarde became increasingly attenuated, as egoism and imagism started to pull apart. The place of the literary (and of avant-garde literature in particular) was thus perhaps a more acute and troubled issue in the early twentieth century than in nineteenthcentury periodicals, but it may also echo the contested and difficult place of the literary in Romantic and Revolutionary contexts.

Recent research and writing on modernist magazines, and modernist literature more generally, has focused on their uses of the machinery of modern commercial culture and the emergent mass media, with manifesto-making, advertising and 
publicity seen as central to periodical literature as, indeed it was to feminist and suffrage campaigns. This work has contributed to the substantial revision of a previously dominant model: that of 'the great divide' between mass and modernist/minority culture. For Mark Morrison, radical movements and their magazines in the early twentieth century 'reveal the surprising imbrication of counterpublic spheres and commercial mass market culture, and this understanding challenges a vision like Habermas's that sees commercial mass market print culture as presenting no possibility other than the degeneration of public deliberation'. The concept of the 'counterpublic sphere' denotes those discursive spaces outside the dominant public sphere which were, at the turn of the nineteenth and twentieth centuries, occupied by suffragists and radical political groups: the argument is that the rise of a commercial mass culture made such counterpublic spheres possible. ${ }^{6}$ This model of the renewal of the public sphere, through simultaneous opposition and engagement, also leads us back to the end of the eighteenth century: to the debates which it has engendered, which are the locus of continued fascination and exploration.

\footnotetext{
${ }^{1}$ Marilyn Butler, 'Culture’s medium: the role of the review', in Cambridge Companion to British Romanticism, ed. Stuart Curran (Cambridge: Cambridge University Press, 1993), p. 127. See also Jon P. Klancher, The Making of English Reading Audiences, 1790-1832 (Madison: University of Wisconsin Press, 1987), pp. 18-46.

${ }^{2}$ See Mark Morrison, The Public Face of Modernism: Little Magazines, Audiences, and Reception 1905-1920, (Madison, University of Wisconsin Press, 2001), pp. 84-133.

${ }^{3}$ Laurel Brake, Print in Transition 1850-1910: Studies in Media and Book History (Basingstoke: Palgrave, 2001), p. 147.

${ }^{4}$ Lytton Strachey, 'Dostoevsky’, in Spectatorial Essays (London: Chatto \& Windus, 1964), pp. 174-9.

${ }^{5}$ Letter from T.S.Eliot to Koteliansky, 11 Jan 1923 (Koteliansky Letters, British Library Volume 9)

${ }^{6}$ Morrison, The Public Face of Modernism, p. 85.
} 